\title{
LA INVERSIÓN DE LA CARGA DE LA PRUEBA: la experiencia latinoamericana peruana
}

\author{
Enrique Varsi Rospigliosi*
}

Resumo: No Peru, a Lei 28547, de 08.01.2005, regulamenta procedimentos para o estabelecimento da filiação. A paternidade é imputada ao pai, declarada pela mãe. Um único caminho é admitido para contestação: submeter-se a exame em DNA, em um período de até dez dias após a notificação.

Palavras-chave: filiação, paternidade, identidade, Direito de família, DNA.

La filiación es un tema recurrente, un problema de muchos, más aún en estos últimos tiempos en que la filiación es vista como una institución dirigida a la protección del hijo, ${ }^{1}$ de la hija.

En la actualidad, existe una fuerte y marcada tendencia a un tratamiento unívoco de la filiación que no distingue entre la matrimonial y la extramatrimonial ${ }^{2}$ como es el caso del sistema brasilero (arts. 1591 y ss del Código civil) y el de Québec que expresamente señala que todos los menores con filiación establecida tienen los mismos derechos y obligaciones, sin importar las circunstancias de su nacimiento (art. 522) y la filiación paterna y materna está dada por el nacimiento, sin importar las circunstancias de nacimiento del menor (art. 523).

\footnotetext{
Doctor en Derecho e professor en la Universidad de Lima.

Este trabajo es un resumen del Proyecto de Investigación denominado El Moderno Tratamiento Legal de la Filiación Extramatrimonial. En razón de la Ley 28457 y La Acción Intimatoria de Paternidad, auspiciado por Instituto de Investigación Científica y financiado por la Universidad de Lima (Perú).

Recebido em 14 fev. 2006 e aprovado em 26 out 2006.
} 
Tal como se presenta la relaciónfilial, como institución esencial del Derecho de familia, su estudio tiene un corte crítico que busca la modernización de sus normas. Implica en gran medida remecer los cimientos de la familia tradicional, echar por la borda varios siglos de tradición jurídica, de doctrinas que en algún momento fueron vanguardistas y que hoy son historia, casi consideradas leyendas, grandes obras de la mitología jurídica.

Es en ese sentido, que diversos factores impulsaron la reforma de la filiación en el Código civil Peruano. Años de trabajo en la formulación de sin número de proyectos de ley en materia filial, la velada esperanza de que la jurisprudencia en familia tome un nuevo rumbo en pro de la filiación, los procesos de paternidad incrementándose día a día, sin encontrar solución, generaron como consecuencia lógica y necesaria que el 8 de enero del 2005 se dictara la Ley 28457 que aprueba un proceso especial para investigar la paternidad extramatrimonial.

\section{Del proceso de filiación}

Ladeterminación de la paternidad consisteen el establecimiento jurídico de la filiación adecuándosele a su fundamento natural: la procreación. Se presenta, entonces, como la constatación jurídica de la paternidad biológica ${ }^{3}$ lo que consagra su esencia basada en el interés social y el orden público.

La Ley 28457 nos ofrece, justamente, un proceso sustentado en resultados periciales científicos basados en la prueba de ADN, cuya fuerza, contundencia y exactitud generan una convicción plena en el juzgador. Siguiendo este razonamiento, el proceso propuesto es ágil, sui géneris creado para dar solución al problema social de la paternidad extramatrimonial, dejando para otros casos los juicios comunes, ventilados en procesos de conocimiento. Las características que presenta este proceso marcan la pauta de especialidad de cómo se enfrentará el problema social de la paternidad no reconocida.

Este proceso es un producto peruano. Es una creación del sistema, con algunas referencias en el derecho comparado, en 
específico del proceso monitorio, que si bien trata de aspectos patrimoniales, la fuerza del compromiso entre las partes conlleva que sea resuelto judicialmente. Se llega a crear algo verdaderamente nuevo y original en materia procesal en defensa de uno de los derechos sustantivos más humanos que existen. Es un proceso especial ex code, no tratado en el Código procesal civil. ${ }^{4}$ Ninguno de los procesos del Código cumplían con satisfacer adecuadamente la pretensión de paternidad y la fuerza probatoria del ADN. Este vacío legal fue subsanado mediante la promulgación de la Ley analizada. Es decir, el legislador optó, preferentemente, por dictar una ley en vez de modificar el Código procesal civil, produciéndose el denominado fenómeno de la descodificación. Esta situación no es mala política legislativa, por el contrario, se trata de leyes concebidas al margen del Código procesal y del civil que cuentan con la misma sistemática, buscando complementar eficazmente sus deficiencias y vacíos.

\section{Características}

El proceso, como queda expresado, es especial. Su singularidad está representada en un conjunto de características que lo connotan, otorgándole un nivel diferenciador de los demás procesos, involucrando el nuevo proceso de paternidad extramatrimonial juez competente, tiular de la acción y sistema abierto.

\section{a. Juez competente}

Es competente para conocer los procesos de declaración judicial de la paternidad extramatrimonial el juez de paz letrado.

La propuesta se sustentó en que no existiendo mayor complejidad en la probanza en el nuevo proceso, sino únicamente fallar en base al resultado genético, la actividad del juez es mínima por lo que se consideró que esta labor podría ser realizada por el juez de paz letrado. Un proceso de mero trámite no requiere ser 
visto por un juez especializado. Además, la competencia de paz es más accesible a los justiciables, tanto por razones geográficas como sociales e ideológicas. La filiación es un tema tan de la de vida que este juez es el más idóneo para conocerlo. A través de este proceso y de su canalización en esta competencia se busca una cultura de paz en la medida que se trata de prevenir conflictos personales y sociales, todos en general, desde sus orígenes. ${ }^{5}$ Finalmente, se logra descargar la labor de los jueces especializados en familia.

Con su agudo análisis, el procesalista Ariano Deho alude que "Es muy probable que se le haya atribuido la competencia al juez de paz letrado por el noble argumento de 'facilitar el acceso' y el, no tan noble, de 'evitar la casación', es decir, para que el asunto muera en línea de tendencia ante el propio juez de paz letrado o, a lo más, ante el juez de familia (artículo 5 de la Ley) sin perturbar ni un poco con estas cuestiones ni a las Salas de la Corte Superior ni, por cierto, a las Salas de la Corte Suprema. Ergo, por implícito, el legislador descarta que este tema pueda dar lugar a problemas de 'nomofilaquia' que precise de la intervención de la Corte Suprema. Lo que es todo decir". ${ }^{6}$ La verdad, tiene razón, y en este caso bastan las palabras de la citada. La filiación como tal y con las pruebas aportadas por la ciencia pueden ser tratadas perfectamente por el juez de paz, además requieren de un proceso ágil y rápido.

\section{b. Titular de la acción}

La regla general que contempla el Código civil es que las acciones de paternidad son personales. El artículo 407 de este establece que la acción judicial de paternidad extramatrimonial corresponde "solo" al hijo. Es éste quien tiene la legitimidad para obrar $^{7}$ pudiendo la madre actuar en su representación si el hijo fuera menor de edad. En cambio, la nueva ley permite a "quien tenga legítimo interés" poder accionar en paternidad a favor de un tercero.

Este es un cambio importante en el que se toma en cuenta el interés moral o familiar (art. VI del Título preliminar del Código 
civil) para iniciar la acción. Puede aludirse que esto implica una intromisión en la intimidad de la persona al decidir en su nombre, y por ella, investigar su esencia filial pero, tratándose de una acción iniciada en defensa de los intereses del menor puede ser justificable, amparable en el sentido de que sus efectos repercutirán en el aspecto personal y colectivo.

\section{c. Sistema abierto}

Todas las características detalladas nos llevan a sostener que el sistema de investigación de la paternidad extramatrimonial asumido es uno de tipo abierto. No sólo porque es flexible y admite todo tipo de pruebas, sino porque, fundamentalmente, el aspecto biológico es el que marca el norte. Se facilita la indagación, se reconoce la libertad en la averiguación del nexo parental, sin restricciones. Descartadas las posiciones basadas en los desaires, ofensas y escándalos que con este accionar puedan producirse. ${ }^{8}$ Todo al más puro estilo minimalista, menos es más ¿Qué duda cabe! Marca la importancia por el fondo, no por la forma. La precisión es su carta de garantía. Queda atrás la apariencia, incertidumbre, frente a la seguridad. Se reduce al máximo, se condensa, la relación paterno filial con el único objetivo: alcanzar la realidad. Adiós los barrocos juicios de paternidad.

Este nuevo estatuto filiativo en materia de paternidad extramarital está sustentado en el derecho a la identidad, en el interés superior del niño y en una sociedad con valores claros, que empiezan donde se inicia toda relación humana, en el seno de la familia con el sólido compromiso de los padres. El que es bueno en familia, es también buen ciudadano (Sófocles). La falta de reconocimiento, negar el legítimo derecho de un niño a tener un padre, es una forma de violencia familiar.

La indefinición de la paternidad, la naturaleza de la mujer de ser "madre", de haber parido y criado a la descendencia, hecho que no sucede con el hombre - aparte del machismo -, los largos 
senderos, trochas incluidas, para discutir el parentesco en fríos y estancos estrados judiciales fueron cuestiones adicionales que acompañaron la poca fortuna de los procesos filiales.

Los perjudicados directos: el hijo y la madre. El primero sin una identidad definida, la segunda cargando toda la responsabilidad de formar una persona, un ciudadano. Las leyes en este tema no se adecuaron a la realidad. La mujer y su descendencia, que dicho sea de paso, no sólo es de ella, sino de aquel que colaboró en el engendramiento, merecen todo el respeto y acción de la ley.

\section{Del trámite}

La diferencia con el proceso de conocimiento, por el que se regía anteriormente esta filiación, es abismal. Por decir lo menos se da un giro de 180 grados que lo hace incomparable con la gestión procesal anterior y con otra existente en razón de su singularidad. Se reducen etapas, actos, plazos. Cuenta con un trámite que podemos esquematizar de la siguiente forma:

\section{a. De la demanda}

El proceso se sintetiza en la presentación de una demanda ante el Juez de Paz Letrado que, a pedido de parte interesada, expedirá una resolución declarando la paternidad.

\section{b. De la defensa, oposición y el mandato de paternidad}

\section{De la defensa}

La única defensa del emplazado frente a la demanda es oponerse al mandato de paternidad sometiéndose a la prueba de ADN, en el plazo de diez (10) días siguientes. No cabe otro tipo de sustento que la oposición en sí misma. Son impertinentes las tachas, los fundamentos de hecho en un escrito de contestación o cualquier 
otro argumento tendente a desnaturalizar, descalificar la efectividad del proceso.

\section{Costo de la prueba}

La norma indica de manera expresa que el costo de la prueba debe ser asumido por la parte demandante que, como sabemos, en la mayoría de los casos es la madre. Y ¿Por qué no la paga el que se opone? al final de cuentas es quien está haciendo uso del derecho de defensa a través de la oposición. Punto interesante, la demanda de paternidad implicaría un precio al demandado que sería reembolsado en caso la prueba genética lo descarte.

\section{Inversión de la carga de la prueba}

La inversión de la carga de la prueba constituye una excepción al principio "quien alega debe probar", contemplado en el artículo 196 del Código adjetivo. Si bien lo común es que quien alegue un hecho debe probarlo, se ha previsto la posibilidad del traslado de la carga de la prueba al demandado por disposición ex lege, lo que obedece a un fin práctico que facilite a quien alegue un hecho demostrar la verdad o falsedad de este, sin tener la carga procesal de probarlo, en mérito de factores razonables, en este caso la efectividad de la prueba genética, el interés del niño.

En el nuevo proceso de filiación extramatrimonial tiene lugar la excepción al principio "quien alega debe probar", y por ello, es el padre (ya declarado así por mandato del juez) quien deberá demostrar la no vinculación filial imputada por la madre. En principio, la carga de la prueba le correspondería a la madre e hijo, pero por disposición de la Ley 28457 se invierte y es trasladada al padre.

En este proceso de filiación corresponde al demandado la incumbencia de probar su no paternidad, mutatis mutandis desdecir la pretensión de filiación extramatrimonial que le es demandada en torno a un sustento probatorio definitivamente categórico que debe ser usado en su defensa. En efecto, en caso de que el demandado incumpla someterse a la prueba de ADN, el mandato del juez se 
convertirá en declaración judicial de paternidad. El demandado deberá soportar las consecuencias de su inactividad probatoria.

\section{Del mandato de paternidad}

Éste es el acto más importante del proceso, además de ser el primero que dicta el juez sin necesidad de escuchar al demandado, inaudita altera pars, "de esta forma el juez si bien resuelve oyendo a una sola de las partes, lo hará no solo sobre la base del relato fáctico, sino a las pruebas aportadas. Y si el emplazado no formula oposición alguna, la cosa juzgada material no solo es consecuencia de su conducta procesal, el silencio o falta de oposición, sino del relato del demandante y los medios probatorios que aportó para sustentarlo". ${ }^{\circ}$

El mandato de paternidad es una resolución judicial compleja. ${ }^{10}$ Es un auto que al notificarse da inicio al proceso. No es un acto de ejecución forzada de la prueba de $\mathrm{ADN}$, todo lo contrario, es una forma de coerción, pues el mandato conlleva una exhortación al sometimiento a la prueba biológica, que de no realizarse en el plazo indicado se decretará la paternidad. Sus efectos son expectaticios, están sujetos a una condición resolutoria de que la prueba no sea realizada en plazo estipulado.

\section{c. Declaración de paternidad. Sentencia}

La sentencia en estos procesos pueden tener varios tipos de fallos.

Declara la paternidad

- En mérito a los resultados positivos de la prueba genética. En esta sentencia la verdad real coincide con la verdad formal. El ADN contribuye eficazmente en el establecimiento de la relación parental.

- En mérito de la no oposición. Transcurrido el plazo y no habiéndose opuesto y llevado a cabo la pericia por causa injustificada el mandato se convierte en declaración de filiación. Sin certeza de paternidad, solo por la no 
realización de la bioprueba se dicta sentencia. Parece un fallo sin contenido, pero no es así. Es la sanción por no colaborar con la verdad. La filiación en estos casos se establece no por el ADN, sino por una presunción legal. Se elimina la certeza científica que proporciona la prueba genética, subsistiendo la incertidumbre, como dice Martel Chang. ${ }^{11}$

\section{No declara la paternidad}

- En mérito del descarte extraído por la prueba genética actuada a través de la oposición del demandado.

Por otro lado, la sentencia declara el nexo filial teniendo como sustento el aspecto biológico, la esencia genética que se encuentra fundamentada en la prueba de ADN. La motivación de estos fallos no debe ser exhaustiva ni referirse a hechos, que pueden existir, sólo debe merituar los resultados de la pericia y fallar la paternidad. La discreción del magistrado se transforma en convicción. El grado de efectividad de la pericia genética es reconocido unánimemente incluso en los sistemas más tradicionales o conservadores como el boliviano, cuando refiere que las pruebas biológicas representan un "elemento probatorio que otorga al juzgador una convicción plena para dirimir la pretensión y la controversia jurídica de paternidad". ${ }^{12}$

\section{d. Apelación}

En mérito de la pluralidad de instancia ${ }^{13}$ cabe la apelación respecto de la declaración de paternidad en el plazo de tres (3) días, teniendo el Juez de Familia diez (10) días para resolver.

Como está redactada la norma, la apelación es una facultad expresa reconocida al demandado a efectos de contradecir la sentencia que lo declara padre.

\section{e. Procedimiento. Resumen}

El proceso y sus actos se pueden resumir de la siguiente manera: 


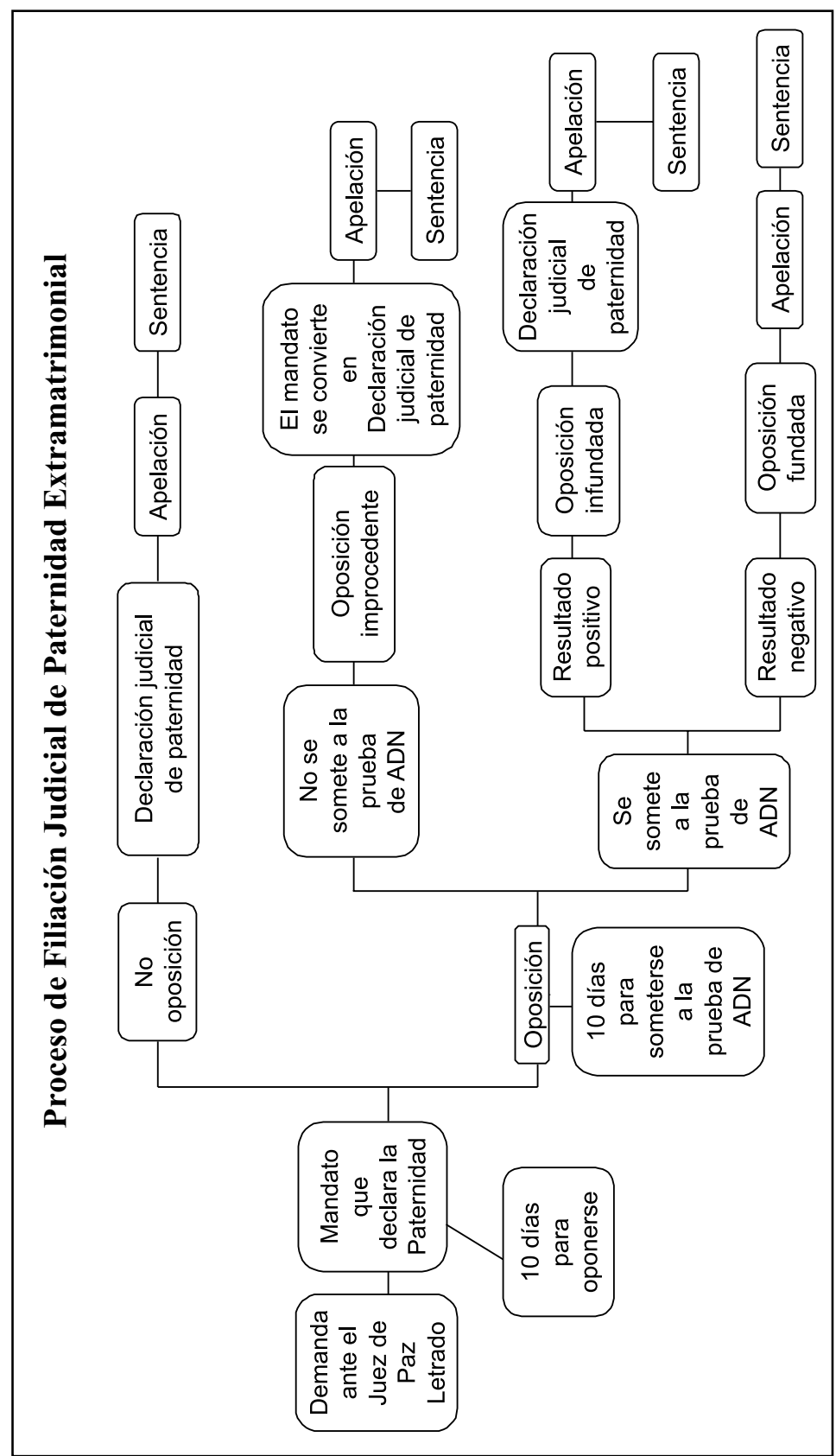


El proceso es sencillo y de fácil realización. Implica la simplificación de procesos en aquellas pretensiones que ameritan ser defendidas de forma eficaz cuando exista un medio de probanza de garantía.

\section{Antecedentes normativos}

Es en el verano del 2004 que mediante una iniciativa legal en las propuestas de la CERIAJUS, Comisión especial de reforma integral de la administración de justicia, ${ }^{14}$ se proyecta la necesidad y se desarrolla un texto normativo que detallaba el proceso especial de filiación. Esta propuesta normativa es asumida luego como proyecto legislativo ${ }^{15}$ por varios congresistas, plasmada recién el 8 de enero de 2005 en la Ley $28457 .{ }^{16}$

El fundamento fue:

La propuesta procura enfrentar de manera expeditiva, económica y equitativa uno de los problemas sociales más graves y extendidos en el país. Casi un millón y medio de personas tienen directa o indirectamente problemas de filiación extramatrimonial. La idea ha sido contar con un procedimiento propio que respetando los derechos de los involucrados, pero utilizando medios coercitivos y eficaces, permita alcanzar justicia de manera oportuna. ${ }^{17}$

El último Censo Nacional (2005) determinó un estimado de 616 mil nacimientos anuales (proyección del 2005 al 2010) pero no se tiene datos del número de niños sin padre, faltos de reconocimiento, labor que, en levantamiento de información, le compete a la RENIEC (Registro nacional de identificación y estado civil).

La filiación es un problema muy sensible, humano de por sí, que el Estado debe asumir con responsabilidad regulando legalmente la formalización del nexo filial de las personas, en especial los lazos de paternidad. ${ }^{18}$ La cifra es abrumadora, de un millón y medio de niños sin un padre. Niños con vivencias y experiencias compartidas solo en una línea familiar, la materna.. En estos casos nada se conoce 
del padre, menos sus ascendientes paternos, "fuera de mi madre ... no tengo noticia de ninguno de mis ascendientes, si no es de Adán, cuyo parentesco me parece indiscutible" (Trafalgar, Benito Pérez Galdós). Futuros ciudadanos que crecerán con un estigma, con una herida que el Estado no supo curar en el momento adecuado, en la niñez. La paternidad es una exigencia, debe ser asumida de forma instantánea, casi conjuntamente con el nacimiento, no tiene por qué aguardar. La vida no espera, continúa.

\section{Justificación del proceso}

Lo decimos una vez más, la justificación para la formulación y aprobación de este proceso fue la contundencia de la prueba de ADN. Los resultados efectivos que de ella pueden obtenerse para establecer quién es el padre no merecen mayor discusión. Si certeza existe en la prueba de la pretensión a invocarse, el proceso debe ser ágil, de prontitud y eficacia en mérito de lo reclamado.

Con esta base y en virtud al bonum filii ${ }^{19}$ se buscó dar solución al incremento cada vez mayor de madres solteras, la irresponsabilidad de los progenitores, lo dificultoso de los procesos de paternidad (largos, costosos, tanto más que la angustia de los litigantes) y a la gran cantidad de niños sin padre (por sobre encima del millón).

\section{Importancia de la norma}

Todos tenemos un padre y una madre, no existe justificación para carecer de uno o de otro. Ningún hijo es del viento o de la aurora $^{20}$, todos tenemos un anclaje, unas raíces. Más allá de la ley, de su imperio, habría que buscar sensibilizar las relaciones humanas encontrando el espíritu de la norma. Padres de ley sin compromiso moral no es tampoco lo que buscamos.

Al menos la ley dictada, y el procedimiento aprobado, buscan solucionar el problema de la paternidad. Es una solución de fondo y también de forma. Se declara una paternidad a falta de voluntad 
expresa, reconociéndose exclusivamente la verdad biológica, aunque no coincida con la socioafectiva. Esto último es, qué duda cabe, discutible.

\section{De sus opositores y los supuestos derechos violados}

Como de costumbre opositores a la ley de intimación de paternidad no faltan. Sostienen, con un personal razonamiento amparado en el derecho constitucional que los medios propuestos por la ley resultan restricciones gravosas de los derechos a la intimidad y a la integridad del presunto progenitor dado que, prácticamente, con el dicho de la parte demandante se declarará una paternidad y se impone una obligatoria actuación de la prueba de ADN para oponerse al mandato de paternidad ${ }^{21}$ lo que vulnera el derecho a la defensa, y por ello inconstitucional. ${ }^{22}$ Vayamos por partes.

\section{a. Derecho a la libertad}

Considero que el sometimiento a las pruebas genéticas para investigar la paternidad es una colaboración obligatoria que de ningún modo atenta contra la libertad individual, en razón de que las técnicas de averiguación de la paternidad son sencillas y no implican una violación al derecho a la autodeterminación del individuo, quien alegue tal restricción comete un abuso de derecho. ${ }^{23}$ Entiéndase claramente que el abuso del derecho es una conducta que se sustenta en un derecho subjetivo que se convierte en antisocial al transgredir un deber jurídico que cristaliza el valor solidaridad. ${ }^{24}$ Esto encaja de manera precisa a nuestra posición.

No puede señalarse que la aplicación de la ley implica una coacción ... eso no es así. Coaccionar — jurídicamente hablando - es "obligar" a alguien a realizar lo no querido ¿Acaso esta ley obliga?, no. La ley no obliga. Solo establece como requisito de procedibilidad a la oposición el sometimiento a la prueba de ADN. Mi libertad es un derecho que debo realizarlo, pero no puedo sobre 
ejercerlo ni forzarlo a límites de mi individualidad, de mi provecho personal. La simple decisión de un hombre puede importar el destino de los demás, en estos casos más aún.

\section{b. Derecho a la intimidad}

El acto íntimo generador de vida no puede ser esgrimido como medio de defensa para objetar la pesquisa filial. Por el contrario, es el medio más directo para escudriñar el origen parental. Mizrahi con claridad se encuadra dentro de este razonamiento "El derecho del hijo a obtener su filiación no se inscribe en la esfera de privacidad del presunto progenitor, pues media un interés social en que aquel obtenga el emplazamiento que le corresponda, lo cual conlleva a observar una actitud de respeto a los posibles vínculos familiares. Por lo demás, y esto nos parece fundamental, es verdad que el propio accionado dejó de lado su propia intimidad, al transportar fuera de sí su propio material genético". ${ }^{25}$ Con la misma idea y razón la profesora Hernández Díaz-Ambrona considera que "Debe prevalecer el interés social y el orden público inherente a las pruebas sobre el derecho a la intimidad del presunto progenitor y porque entra en juego los derechos de los alimentos y sucesorios". ${ }^{26}$

\section{c. Derecho a la integridad}

¿Qué integridad puede violarse si la prueba de ADN es inofensiva respecto de la santidad del cuerpo? No requiere de una inspectio corporis exhaustiva, no es necesario pinchazo alguno, las muestras de sangre están descartadas. Técnicamente se necesitan sólo fluidos, secreciones corporales, cabello, mucosa bucal, simplemente eso. La prueba, con lo expuesto, es mucho menos invasiva en el cuerpo de la persona - a diferencia de lo que sucedía con las otras pruebas heredobiológicas - por lo que no puede calificarse de traumática. ${ }^{27}$ 


\section{d. Derecho a la presunción de inocencia}

La paternidad noes un tema de culpa, es materia de compromiso. Si de extremos se trata, llevando al límite lo indiscutible, el ADN también libera. ${ }^{28}$ Libera al hijo de la ausencia de identidad biológico paternal, para enterarse de sus orígenes. El desconocimiento de identidad paternal debe ceder el paso a la verdad, conocida (al menos por regla general) por sus progenitores.

"La importancia de la filiación deriva de la gran responsabilidad que implica haber engendrado a un hijo al cual hay que proteger, formar y garantizar que llegue a la edad adulta con capacidad para desenvolverse en el mundo", ${ }^{29}$ sobre este esquema es que debemos trabajar. Ser padre es más que un derecho de generar descendencia, es un deber. Empieza asumiendo legalmente tal calidad reconociendo, se robustece con el ejemplo que va formando los valores, educando al nuevo ser. La paternidad es una actitud, una forma de ser, de comportarse. Si bien inmiscuye al padre con el hijo, sus raíces trascienden el aspecto meramente personal, trasladando sus efectos al ámbito social. La comunidad, el Estado, la democracia se benefician de una relación paterno filial consolidada. La Constitución y los Tratados Internacionales favorecen el establecimiento de la familia siendo valor entendido que la filiación es la forma más común de formarla. Estos, Constitución y Tratados, además de Convenciones no "pueden ser invocados para negarse a rendir una prueba biológica, pues tal conducta implica desconocer hipócritamente los derechos que emanan de esas mismas normas", ${ }^{30}$ negarse a la prueba biológica conculca el deber que impone la Constitución a todos de velar por sus hijos menores eludiendo una (gran) responsabilidad. ${ }^{31}$

\section{La identidad y la investigación de la paternidad. Dos derechos constitucionales}

Los criterios en contra, hace buen tiempo, fueron tratados y resueltos por la doctrina y jurisprudencia comparada considerando la no afectación de los derechos del demandante en los procesos de 
filiación, tomándose muy en cuenta el principio deproporcionalidad..$^{32}$ Es decir, se valora que las restricciones son equilibradas teniendo como fomento el bien común. Este nuevo proceso de filiación genera todo un análisis en cuanto a su trascendencia en las partes, lo que se aprecia de nuestra posición expuesta.

La paz social, la integridad de la familia, el derecho a la identidad gozan de una prevalencia sobre el derecho del supuesto padre a negar su paternidad.

\section{Visos de conclusión}

La Ley 28457, intimatoria de paternidad extramatrimonial es una buena ley, pero que no representa una solución integral, en todo caso. Tiene sus pro y sus contra, como apreciamos en rigor con este ensayo. Los primeros con mayor ventaja frente a los segundos.

Serán más los beneficiados que los perjudicados. El hijo en lugar del padre, sin enfrentamiento, solo retrepados en verdades. Uno de los dos, el que generó la filiación - no el generado - asumirá un sacrificio en proporción a su acto y responsabilidad. Antes se cometían más abusos, lo ancho para el padre y lo angosto para el hijo fue la consigna del otrora modelo procedimental. Las cosas se revierten. Pensamos que es una solución parcial al problema central en el esclarecimiento del parentesco.

Con el antiguo proceso enrevesado en trámites, papeles, decires, desconociendo la fuerza probatoria de la genética ante el estado de indefensión, de soledad e impotencia de niños sin padres, desconocedores de su identidad, de qué justicia podía hablarse. No se quiere más de lo mismo. Se necesitaba un cambio. Este es uno radical por que la coyuntura lo requiere. Esperemos el desarrollo ordenado de esta nueva era en el estatuto de la filiación, ayudemos a crear una conciencia en nuestros futuros "padres" y en los nuevos "hijos". No dejemos a expensas del litigio la solución de estos casos; en el fondo este proceso desalienta, mejor dicho 
disuade, la paternidad irresponsable tendiendo al reconocimiento voluntario. García Cantero acertadamente constata que "Quizá una de las cuestiones más importantes para el siglo XXI será repensar la paternidad (rethinking the parentood). ${ }^{33}$ " En el Perú estamos dando un primer y decisivo paso.

\section{Notas}

1 KRASNOW, Adriana Noemí: "La filiación y sus fuentes", en: La Ley. Buenos Aires, Tomo 2005 A, Sec. Doctrina, p. 1459.

2 SESTA, Michele: "Derecho de familia italiano. ¿Hacia nuevas transformaciones?”, en: Homenaje a Fernando Hinestrosa. 40 años de rectoría 1963-2003, Colombia, Universidad Externado de Colombia, julio de 2003, p.56.

3 VERDERA SERVER, Rafael: Determinación y acreditación de la filiación, Barcelona, Bosch, 1993, p.16.

4 El Pleno Jurisdiccional Distrital de la Corte Superior de Justicia de Moquegua, realizado el 21 de junio de 2005, acordó por unanimidad: PRIMERO - En tanto la Ley 28457 crea una forma especial de solicitar la filiación de paternidad extramatrimonial, debe cumplirse con la misma y en efecto tramitarse la filiación extramatrimonial, en este proceso especial, dado que el proceso que se ha diseñado por la ley 28457 que modifica el artículo 402 del CC, es un proceso de naturaleza especial que no se ajusta a ninguno de los procesos del Código Procesal Civil ... (las cursivas son nuestras).

5 Vid. Sobre Justicia y la cultura de paz el Capítulo I de GUERRA CERRÓN, María Elena: Hacia una justicia de paz. Un asunto de interés nacional, Lima, Ed. Grijley, 2005, p. 1 a la 12.

6 ARIANO DEHO, Eugenia: "El nuevo proceso de declaración de filiación extramatrimonial. ¿Vanguardismo o primitivismo procesal?", en: Actualidad Jurídica (publicación mensual de Gaceta Jurídica), Lima, tomo 134, enero, 2005, p.65.

7 Cfr. LASTARRIA RAMOS, Edgard: "Titulares de la acción”, en: Código civil comentado, tomo III, Lima, Gaceta Jurídica, julio de 2003, p. 48. 
8 Compartimos con Velez Sárfield quien sostuvo en 1858 su posición contraria a que la indagación de la paternidad sin restricciones podría desencadenar grandes escándalos, chantajes e incluso un atentado contra la moral. $\mathrm{Al}$ respecto, manifestó tajantemente que no se trata de descubrir un crimen sino simplemente (subrayamos simplemente) de determinar quien es el progenitor o los progenitores de una persona, lo que de ninguna manera puede ser un escándalo, por el contrario la prohibición de la indagación de la paternidad destruye las leyes que crean el orden familiar, lo que sí es un escándalo, de tremenda dimensión agregaríamos nosotros. Vid. PALMERO, Juan Carlos: "Vélez Sárfield y el derecho Latinoamérica", en: Homenaje a Dalmacio Vélez Sárfield, Tomo I, Academia Nacional de Córdoba, Córdoba, 2000, p. 245 y 246.

9 MARTEL CHANG, Rolando: Op. cit., p.69.

10 Término utilizado por Herrera Navarro refiriéndose al mandato ejecutivo. Vid. HERRERA NAVARRO, Santiago: Proceso de ejecución, Trujillo, Normas Legales, 2002, p.29

11 MARTEL CHANG, Rolando: Op. cit., p. 70.

12 PAZ ESPINOZA, Félix: Derecho de familia y sus instituciones, $2^{\mathrm{a}}$ edición, La Paz, G.G. Gráfica, 2002, p.340.

13 "TERCERO - En el proceso de reconocimiento de filiación de paternidad extramatrimonial se cumple con el Principio de Pluralidad de Instancias con el pronunciamiento del Juez de Primera Instancia respecto a la resolución pronunciada por el Juzgado de Paz Letrado". Acuerdo por unanimidad del Pleno Jurisdiccional Distrital de la Corte Superior de Justicia de Moquegua, 21 de junio de 2005.

14 Ley 28083, mediante la que se crea la Comisión Especial para la Reforma Integral de la Administración de Justicia - CERIAJUS. Su finalidad fue elaborar el Plan Nacional de Reforma Integral de la Administración de Justicia. Como indica el artículo 1 este Plan debía contener una propuesta global y concertada de reforma de la administración de justicia.

15 Proyecto 10772/2003-CR, 9/6/2004, Paternidad extramatrimonial / Proceso de filiación, Sumilla: Propone regular el proceso de filiación de paternidad extramatrimonial, Proponente: Alcides Chamorro; Proyecto 10919/2003-CR, junio 2004, Código de los niños y adolescentes: 182/ 
Proceso de filiación de paternidad, Sumilla: Propone modificar el artículo $182^{\circ}$ del Código del Niño y Adolescente, referente a la vía procesal especial para filiación, Proponente: Yonhy Lescano Anchieta tomando como base lo aprobado por la Ceriajus; Proyecto 11536/2004CR, 23/09/2004, Filiación extramatrimonial: Sumilla: Propone la Ley que establece el proceso de filiación extramatrimonial, Proponente Fausto Alvarado Dodero. Los tres congresistas fueron miembros de CERIAJUS. El segundo gran impulsor de esta ley, el último dio el do de pecho en el proyecto de reforma del sistema de justicia.

Asimismo, otros proyectos buscaron sumarizar el proceso de filiación: Proyecto 10312, 7/4/2004, Filiación extramatrimonial/ Sumariza el proceso, Sumilla: Propone sumarizar el proceso de filiación extramatrimonial; Proyecto 7471,3/7/2003, Código procesal civil: 546, 547/ Proceso sumarisimo filiación extramatrimonial, Sumilla: Propone modificar los artículos $546^{\circ}$ y $547^{\circ}$ del Código Procesal Civil, referente a que es procedente tramitar como proceso sumarísimo la filiación extramatrimonial; Proyecto 5781, 3/3/2003, Código procesal civil: 546, 547/ Trámite sumarísimo/ Filiación extramatrimonial, Sumilla: Propone modificar los artículos $546^{\circ}$ y $547^{\circ}$ del Código Procesal Civil, e incorpora al trámite sumarísimo a la filiación extramatrimonial.

16 Curiosamente, esta ley no fue promulgada por el Presidente de la República, Alejandro Toledo Manrique, lo que determinó que el Congreso ordenara su publicación y cumplimiento. Parece absurdo que una ley con tanta trascendencia no haya contado ni con la aprobación o, al menos, observación alguna del primer mandatario. Puede presumirse que el caso judicial seguido en su contra sobre declaración judicial de paternidad, que terminó en una transacción reconociendo a Zarai Toledo Orozco, dejó una huella en él. Mayor referencia del caso Vid. Diálogos con la Jurisprudencia, Lima, año 8, n 40, enero 2002.

17 Documento político de la CERIAJUS. Se consideró un plazo: 20042005, el que como puede verse, se cumplió.

18 En un tribunal argentino se argumentó "negar la realización de la prueba importaría desconocer lo establecido en la Convención de los derechos del niño, circunstancia que podría ocasionar la responsabilidad del estado por el incumplimiento de los compromisos internacionales asumidos, toda vez que la prueba ordenada aparece como medio para poner pronta y eficaz solución a la situación del menor”. CSJN, 4- 
12-95. Cfr. KEMELMAJER DE CARLUCCI, Aída: "El derecho de familia en la República Argentina del sglo XXI. Su inexorable proceso de constitucionalización y de adecuación a los tratados internacionales de derechos humanos", en: Revista de derecho comparado, $\mathrm{n}^{\circ} 10$ : Derecho de familia, Buenos Aires, Ed. Rubinzal Culzoni, 2004, p.33.

19 Se ha mencionado con solvencia que el interés del niño tiene tanta importancia que ha sido adjetivado como "superior", "exclusivo", "prevalente", "objeto de primaria consideración" POCAR, Valerio y RONFANI, Paola: La famiglia e il diritto, Roma, Editori Laterza, 2003, p. 157. Con la misma opinión el magistrado ecuatoriano Márquez Matamoros nos da a entender que el interés superior del niño aporta dos lecturas: una individual (protegiéndole a él) y otra colectiva (lograr la paz social) MARQUEZ MATAMOROS, Arturo: Legislación internacional sobre derechos de los niños. Aplicación y obligatoriedad en el Ecuador, Quito, Ed. Abya-Yala, 2000, p. XVIII. Como principio resulta un as con doble cara, en beneficio de uno y en perjuicio de otro. Como diría Kemelmajer, el interés superior del niño es prácticamente "un cheque en blanco" que permite un libre y casi absoluto accionar en defensa de los la niñez. Cfr. KEMELMAJER DE CARLUCCI, Aída: "El derecho de familia en la República Argentina del siglo XXI. $\mathrm{Su}$ inexorable proceso de constitucionalización y de adecuación a los tratados internacionales de derechos humanos", en: Revista de derecho comparado, $\mathrm{n}^{\circ}$ 10: Derecho de familia, Buenos Aires, Ed. Rubinzal Culzoni, 2004, p.9.

20 VALLE, Gabriel: Ética e Directo, Porto Alegre, Síntese, 1999, p. 28.

21 PLÁCIDO VILCACHAGUA, Alex: "Creditur virgini pregnanti..., volviendo al ancien droit: A propósito de la Ley No. 28457 que regula el proceso de filiación judicial de paternidad extramatrimonial", en: Op.cit., p. 33.

22 PLÁCIDO VILCACHAGUA, Alex: "Es inconstitucional obligar al demandado a someterse a la prueba de ADN", en: Legal Express, Lima, año 5, enero 2005, No.49, p.19.

23 VARSI ROSPIGLIOSI, Enrique: Filiación, Derecho y Genética, Lima, Co edición Universidad de Lima y Fondo de Cultura económica, 1999, p.186.

24 FERNÁNDEZ SESSAREGO, Abuso del derecho, Ed. Astrea, Buenos Aires, 1992, p.178. 
25 MIZRAHI, Mauricio Luis: Identidad filiatoria y pruebas biológicas, Buenos Aires, Astrea, 2004, p.99. En esta posición cita el autor jurisprudencia y doctrina Tribunal Constitucional de España, Sala I, 17/1/94, ED, pp.157 a 259; CS Sfe, 19/9/91, LL, 1992-D536; TSJ Córdoba, Sala Civil y Comercial, 4/5/00, “ $N N$. Recurso directo", $L L C$, 2001-22; SC Mendoza, Sala I, 29/8/95-B-546; CNCiv, Sala I, 21/6/01, ED, 194-54; MÉNDEZ COSTA: Encuadre constitucional del derecho a la identidad, LL, 1992-D-536; GÓMEZ: "Compromiso del derecho a la intimidad del demandado en la producción de la prueba biológica -en la especie, de la genética ofrecida por el actor en proceso por su filiación", en: Derecho de Familia, No. 11, p. 67; MODESTA - SÁENZ: "Algo mas sobre el derecho a la identidad", $L L, 1995-A-377$; GROSMAN - ARIANNA: "Los efectos de la negativa a someterse a los exámenes biológicos en los juicios de filiación paterna extramatrimonial", LL, 1992-B-1193; MEDINA, "filiación: negativa a realizar pruebas biogenéticas", JA, 1995-IV-340; ALVAREZ: “Alcances de la negativa del padre a someterse a la prueba hematológica en las acciones de reclamación de filiación extramatrimonial”, $E D, 124-710$; BOSCH (h), "La filiación de las personas y los métodos compulsivos para obtener pruebas", $L L, 2003-\mathrm{B}-1116$.

26 HERNÁNDEZ DÍAZ-AMBRONA, María Dolores: "Notas sobre el derecho a la identidad del niño y la verdad biológica", en: Revista de derecho privado, Madrid, Julio - agosto 2005, p.51.

27 MIZRAHI, Mauricio Luis: Identidad filiatoria y pruebas biológicas, Buenos Aires, Astrea, 2004, p.68.

28 Una jueza de Miami ordenó que el convicto, un hombre de 67 años acusado a cadena perpetua por múltiples casos de violación, fuese absuelto de todos los delitos. La prueba determinante fue una pericia de ADN. Cfr. "Recupera la libertad por una prueba de ADN", en: www. diariojudicial.com. Accesos el 04/08/2005.

29 WEBER, Albretch: "Protección constitucional de la infancia", en: Derechos fundamentales y Estado. Memoria del VII Congreso Iberoamericano de Derecho Constitucional, Coordinar Miguel Carbonell, México, Universidad Nacional Autónoma de México, 2002, p.114.

30 MIZRAHI, Mauricio Luis: Identidad filiatoria y pruebas biológicas, Buenos Aires, Astrea, 2004, p. 123. 
31 HERNÁNDEZ DIAZ-AMBRONA, María Dolores: "Notas sobre el derecho a la identidad del niño y la verdad biológica", en: Revista de derecho privado, Madrid, Julio - agosto 2005, p.51.

32 BERNAL PULIDO, Carlos: El principio de proporcionalidad y los derechos fundamentales, Madrid, Centro de Estudios Políticos y Constitucionales, 2003, p. 519.

33 GARCIA CANTERO, Gabriel: “¿Qué familia para el silo XXI” en: Revista de derecho comparado, No. 9: Derecho de familia, Buenos Aires, Ed. Rubinzal Culzoni, 2004, p.75.

Shifting the burden of proof: the Peruvian experience

Abstract: In Peru, the Law $\mathrm{N}^{\circ} 28457$ (08/01/2005) regulates the action to stablish the filiation. In this way, the presumed father is declared by sentence father of the child. The only way to contest the action - within next ten days since the notification of the action - is to submit to the DNA analysis.

Key-words: filiation, fatherhood, identity, family law, DNA.

\section{Anexo: Texto de la ley}

Ley 28457

El Peruano, 8 de enero de 2005

EL PRESIDENTE DEL CONGRESO DE LA REPÚBLICA] POR CUANTO EL CONGRESO DE LA REPÚBLICA

Ha dado la Ley siguiente:

Ley que regula el proceso de filiación judicial de paternidad extramatrimonial

Artículo $1^{\circ}$ - Demanda y Juez competente

Quien tenga legítimo interés en obtener una declaración de paternidad puede pedir a un Juez de Paz Letrado que expida resolución declarando la filiación demandada. 
Si el emplazado no formula oposición dentro del plazo de diez días de haber notificado válidamente, el mandato se convertirá en declaración judicial de paternidad.

\section{Artículo $2^{\circ}$ - Oposición}

La oposición suspende el mandato si el emplazado se obliga a realizarse la prueba biológica de ADN, dentro de los diez días siguientes. El costo de la prueba será abonado por el demandante en el momento de la toma de las muestras o podrá solicitar el auxilio judicial a que se refieren el artículo $179^{\circ}$ y siguientes del Código Procesal Civil.

El ADN será realizado con muestras del padre, la madre y el hijo.

Si transcurridos diez días de vencido el plazo, el oponente no cumpliera con la realización de la prueba por causa injustificada, la oposición será declarada improcedente y el mandato se convertirá en declaración judicial de paternidad.

\section{Artículo $3^{\circ}$ - Oposición fundada}

Si la prueba produjera un resultado negativo, la oposición será declarada fundada y el demandante será condenado a las costas y costos del proceso.

\section{Artículo $4^{\circ}$ - Oposición infundada}

Si la prueba produjera un resultado positivo, la oposición será declarada infundada, el mandato se convertirá en declaración judicial de paternidad y el emplazado será condenado a las costas y costos del proceso. 
Artículo 5 - Apelación

La declaración judicial de filiación podrá ser apelada dentro del plazo de tres días. El juez de Familia resolverá en un plazo no mayor de diez días. (......)

Comuníquese al señor Presidente de la República para su promulgación.

En Lima, a los cuatro días del mes de diciembre de dos mil cuatro.

ÁNTERO FLORES-ARAOZ E.

Presidente del Congreso de la República

NATALE AMPRIMO PLÁ

Primer Vicepresidente del Congreso de la República

AL SEÑOR PRESIDENTE CONSTITUCIONAL DE LA REPÚBLICA

POR TANTO:

No habiendo sido promulgada dentro del plazo constitucional por el señor Presidente de la República, en cumplimiento de los artículos $108^{\circ}$ de la Constitución Política y $80^{\circ}$ del Reglamento del Congreso, ordeno que se publique y cumpla.

En Lima, a los siete días del mes de enero de dos mil cinco.

ÁNTERO FLORES-ARAOZ E.

Presidente del Congreso de la República

NATALE AMPRIMO PLÁ

Primer Vicepresidente del Congreso de la República 